Utah State University

DigitalCommons@USU

The Bark Beetles, Fuels, and Fire Bibliography

Quinney Natural Resources Research Library,

S.J. and Jessie E.

1991

\title{
Temperature-Dependent Development of the Mountain Pine Beetle (Coleoptera : Scolytidae) and Simulation of its Phenology
}

\author{
Barbara J. Bentz \\ Jesse A. Logan \\ Gene D. Amman
}

Follow this and additional works at: https://digitalcommons.usu.edu/barkbeetles

Part of the Ecology and Evolutionary Biology Commons, Entomology Commons, Forest Biology

Commons, Forest Management Commons, and the Wood Science and Pulp, Paper Technology Commons

\section{Recommended Citation}

Bentz, B., Logan, J. and Amman, G. (1991). Temperature-dependent development of the mountain pine beetle (Coleoptera : Scolytidae) and simulation of its phenology. Canadian Entomologist, 123(5):

1083-1094.

This Article is brought to you for free and open access by the Quinney Natural Resources Research Library, S.J. and Jessie E. at DigitalCommons@USU. It has been accepted for inclusion in The Bark Beetles, Fuels, and Fire Bibliography by an authorized administrator of DigitalCommons@USU. For more information, please contact digitalcommons@usu.edu.

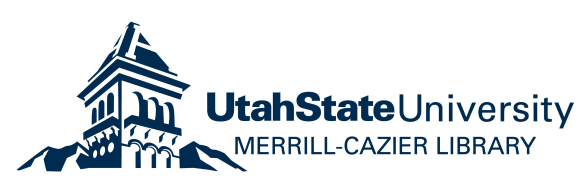




\title{
MPERATURE-DEPENDENT DEVELOPMENT OF THE MOUNTAIN PINE BEETLE (COLEOPTERA: SCOLYTIDAE) AND SIMULATION OF ITS PHENOLOGY
}

\author{
BARBARA J. BENTZ \\ Intermountain Research Station, Forest Service, U.S. Department of Agriculture, Ogden, Utah, USA 84401 \\ JESSE A. LOGAN \\ Department of Entomology, Virginia Polytechnic Institute and State University, Blacksburg, Virginia, \\ USA 24061 \\ and GENE D. AMMAN \\ Intermountain Research Station, Forest Service, U.S. Department of Agriculture, Ogden, Utah, USA 84401
}

\begin{abstract}
Can. Ent. 123: 1083-1094 (1991)
\end{abstract}

Temperature-dependent development of the egg, larval, and pupal life-stages of the mountain pine beetle (Dendroctonus ponderosae Hopkins) was described using data from constant-temperature laboratory experiments. A phenology model describing the effect of temperature on the temporal distribution of the life-stages was developed using these data. Phloem temperatures recorded in a beetle-infested lodgepole pine (Pinus contorta Douglas) were used as input to run the model. Results from model simulations suggest that inherent temperature thresholds in each life-stage help to synchronize population dynamics with seasonal climatic changes. This basic phenological information and the developed model will facilitate both research and management endeavors aimed at reducing losses in lodgepole pine stands caused by mountain pine beetle infestations.

Bentz, B.J., J.A. Logan et G.D. Amman. 1991. Influence de la température sur le développement du Dendroctone du Pin ponderosa (Coleoptera: Scolytidae) et simulation de sa phénologie. Can. Ent. 123: 1083-1094.

\section{Résumé}

On trouvera ici la description du développement de l'oeuf, de la larve et de la nymphe sous l'influence de la température chez le Dendroctone du Pin ponderosa (Dendroctonus ponderosae Hopkins), description élaborée à la suite d'observations en laboratoire dans des conditions constantes de température. Les données ont également servi à construire un modèle de la phénologie de l'insecte qui tient compte de l'effet de la température sur la répartition temporelle des divers stades. Les températures du phloème enregistrées dans un Pin ponderosa infesté de coléoptères ont été intégrées au modèle. Les résultats des simulations indiquent que les seuils thermiques inhérents à chacun des stades contribuent à synchroniser la dynamique de la population avec les changements climatiques saisonniers. Cette information phénologique de base et le modèle que nous avons mis au point faciliteront les tentatives de recherche et d'aménagement entreprises dans le but de limiter, dans les forêts de Pins ponderosa, les pertes occasionnées par les infestations de dendroctones.

[Traduit par la rédaction]

\section{Introduction}

The mountain pine beetle (Dendroctonus ponderosae Hopkins), a univoltine species that infests living pines, is a common insect pest in stands of lodgepole pine (Pinus contorta Douglas). Adults generally attack susceptible hosts in late July, bore through the bark into the phloem tissue, and construct vertical egg galleries. Larvae emerge and feed upon the phloem tissue, usually killing the host tree. The beetle typically overwinters as third- or fourth-instar larvae which resume development in the spring. Pupation occurs in early summer followed by a teneral adult stage shortly before adult emergence in late July or early August. Due to climatic effects, more than 1 year may be required for a generation at high altitudes or extreme northern latitudes (Amman 1973).

All life-stages of the mountain pine beetle are exposed to a changing habitat due to alterations in the chemical and physical composition of the host tree (Berryman 1972; 
Langor 1989) and the surrounding microclimate (Bartos and Amman 1989). Moisture, food availability, resin pressure, predator/parasite complexes, and temperature are factors that influence mountain pine beetle phenology. Of these, the effect of temperature has been studied most extensively. Temperature affects the physiological events that regulate coldhardiness and largely determines the rate of development for each individual. Early studies revealed seasonal and regional differences in cold-hardiness among mountain pine beetle life-stages, as well as considerable variation among individual mountain pine beetle larvae in their resistance to cold temperatures (Beal 1934; Bedard 1940; Yuill 1941; Wygant 1942).

Studies by Amman and Cole (1983) suggest that each larval instar has a specific developmental threshold. Although extreme winter temperatures are thought to be the most important mortality factor of mountain pine beetle populations (Cole 1981), the indirect effects of microclimate may also strongly influence the timing of critical life-history events and probably play an important role in determining survival of the population. To understand more fully how microclimate affects mountain pine beetle populations, it is necessary to investigate each life-stage separately. Due to the cryptic habitat of bark beetles, however, measuring development in response to temperature is difficult. Consequently, typical approaches in bark beetle studies have not considered variation among the larval instars. Other than the model of mountain pine beetle egg development by Logan and Amman (1986), descriptions of the influence of temperature on the mountain pine beetle have been restricted to general observations and day-degree models for egg hatch (Reid and Gates 1970), general larval development (Amman and Cole 1983; McCambridge 1974; Safranyik and Whitney 1985), and adult emergence (Powell 1967; Reid 1963). This approach, in which all larval instars are combined, is adequate in habitats where effects on the development of each life-stage are constant or the development of each life-stage is consistent throughout the life cycle. Neither of these situations is necessarily true for the mountain pine beetle.

Because the relative temporal distributions of insect life-stages often play a vital role in the survival of a population, understanding the phenology of insect development is central to the study of population dynamics, as well as to pest management concepts. Our objectives in this study were as follows: (1) to describe the temperature-dependent phenology of the eggs, larval instars, and pupae of the mountain pine beetle, and the inherent variation due to microclimate; (2) to use these data to develop a simulation model of mountain pine beetle phenology; and (3) to test hypotheses concerning mountain pine beetle life-history strategies using the developed simulation model.

\section{Methods}

Constant-temperature Experiments. Green lodgepole pine in the Wasatch National Forest, UT, were cut into billets and brought to the laboratory at Ogden, UT. Circular pieces of bark, $20 \mathrm{~mm}$ diameter, were cut from each billet. Seven to 10 small holes, representing egg niches, were cut into the phloem tissue of each bark circle. Newly emerged females from billets cut in the same stand were allowed to oviposit in green logs. The bark containing the egg gallery was then removed and eggs were extracted using a sterilized teasing needle. One mountain pine beetle egg was placed into each artificial niche, and the bark disk then was placed phloem side down into a Petri dish. To keep the bark disk flat and tightly compressed against the bottom of the Petri dish, a circular piece of plyboard and the dish lid were placed on top and secured with several strong rubber bands. Bark disks were placed in humidifiers over a saturated solution of potassium sulfate that maintained relative humidity near $100 \%$ and prevented drying of the phloem. Five to six eggs oviposited during the previous $24 \mathrm{~h}$ were placed in each bark disk. The disks were then placed in incubating chambers, six at each of 11 different temperatures $(5,8,10,12.5,15,17.5$, $20,22.5,25,27.5$, and $30^{\circ} \mathrm{C}$ ). 
After egg hatch, individual larvae were observed, and development was checked twice daily. Larval molts were determined by the head capsule color and size (Reid 1962; Amman and Cole 1983). Occasionally, some larvae submerged into the phloem tissue and observations were not made until they resurfaced. Therefore a complete developmental history was not available for each of the individuals at each constant temperature. Because only a few individuals survived to the fourth larval instar, the experiment was repeated. In the second experiment, the disks were placed at room temperature until individuals molted to the third-instar. After that time the disks were placed in incubating chambers at the 11 temperatures noted above and individuals were observed and development recorded until pupation to the teneral adult occurred.

Phloem Temperature Measurements. Phloem temperatures were recorded (21X Micrologger, Campbell Scientific) in a $25.1 \mathrm{~cm}$ dbh (diameter at breast height) beetle-infested lodgepole pine in the Sawtooth National Recreation Area (SNRA), ID $\left(43^{\circ} 53^{\prime} \mathrm{N}\right.$ latitude, $114^{\circ} 50^{\prime} \mathrm{W}$ longitude, $2260 \mathrm{~m}$ altitude). Temperatures were recorded hourly, approximately . $37 \mathrm{~m}$ from the base of the tree on the north and south sides of the bole, from Julian day 221,1989 , to Julian day 219, 1990.

Developmental Rate Versus Development Time. Developmental rate is defined as the inverse of the time required to complete an instar or life-stage. Traditionally, for both conceptual and computational convenience, insect phenology models have used a physiologic time-scale based on rate, as opposed to the originally measured developmental time. However, there are several problems associated with using the inverse of time(rate), rather than time itself when estimating model parameters (Kramer et al. 1991). One problem is in the least-squares estimation technique, where the error between observed and predicted values is minimized. Because of the nonlinearity of the rate transformation (1/time), minimizing the error between observed and predicted developmental times is not the same as minimizing the error between the associated developmental rates. A disproportionate amount of weight is given to values at temperatures where faster developmental rate occurs. For example, the difference between two slow rates $(0.01$ and 0.02$)$ is 0.01 . The error in time associated with these rates is 50 days. At higher temperatures where faster rates occur (e.g. 0.28 and 0.29$)$, the rate difference is the same $(0.01)$, but the associated error in time (0.123 days) is quite different. Therefore an error in developmental time does not coincide with the same error in its inverse, developmental rate, at all temperatures.

To overcome this problem, weighting the least-squares estimation with $1 /$ rate or $1 /$ rate $^{2}$ has been suggested (Wagner et al. 1984). An alternate solution is to estimate parameters using the inverse of the developmental function fitted to the original developmental time data. Figure 1 illustrates the residuals from parameters estimated from both developmental rate and developmental time data, compared with the residuals from the leastsquares estimation weighted with $1 / \mathrm{rate}^{2}$. At low temperatures, residuals from parameters estimated from developmental time were smaller than those from either the model estimated using rate data or the $1 /$ rate $^{2}$ weighted least-squares estimation. At higher temperatures, results from the three methods were similar. These observations suggest that when development at low temperatures is important or when development occurs over a long time span, fitting developmental functions to time data should produce a more accurate representation of phenology. We therefore estimated parameters for the developmental functions using time data.

Phenology Model Development. The response of insect development to constant temperatures has been studied extensively and the functional forms required to adequately describe this phenomenon are well known. Fitting developmental data to one of these models is therefore not an arbitrary statistical procedure, but is based on ecological knowledge. Median developmental times for mountain pine beetle eggs, larval instars, and pupae 


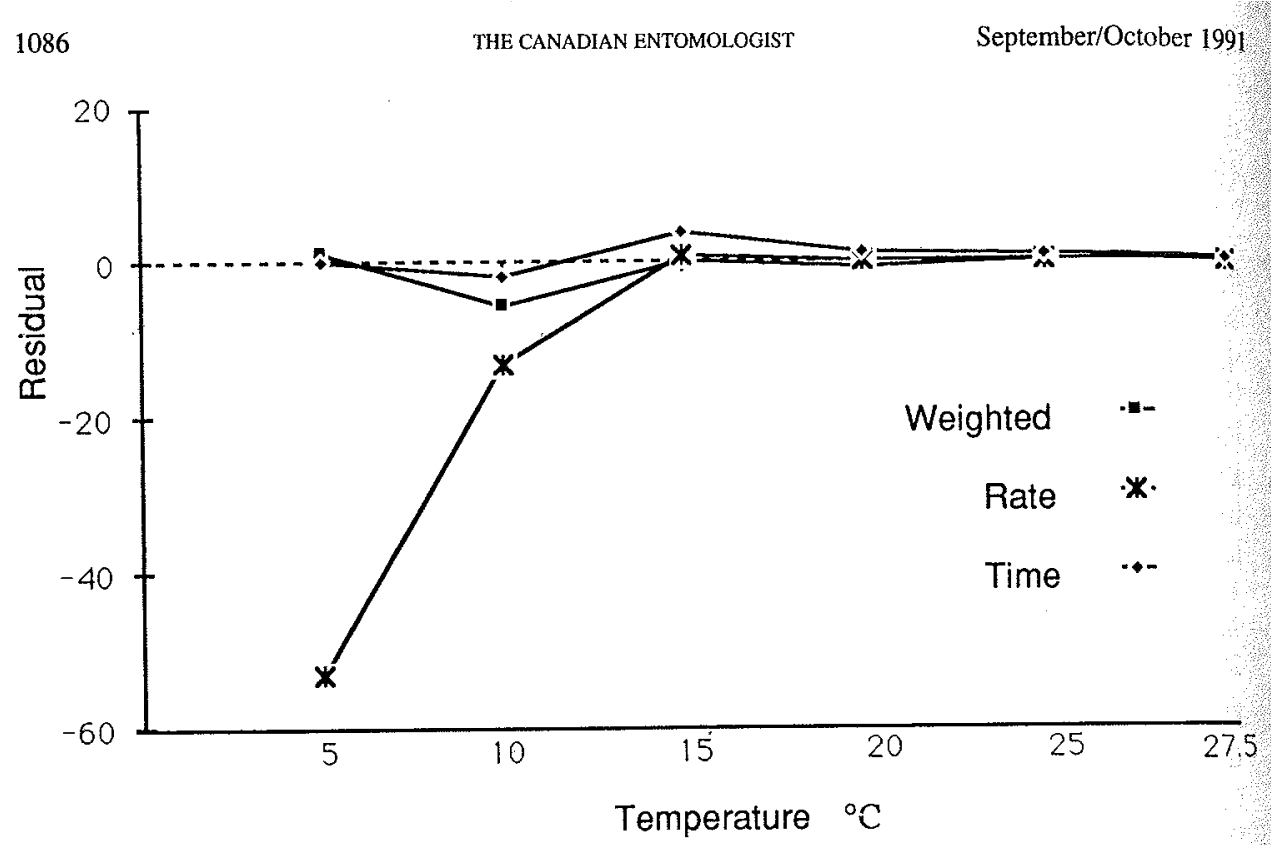

Fig. 1. Residual values (observed days minus predicted days) using model TM2 (see Table 1) with observed time data, developmental rate data, and the least-squares estimate weighted with $1 /$ rate $^{2}$.

were fitted to one of eight previously derived developmental models included in the Population Model Design System (PMDS) (Logan 1988). As described above, the inverse of the developmental function was fitted to the developmental time for each life-stage. Curve fitting was accomplished either through linear least-squares regression or a nonlinear leastsquares procedure. Ecological assumptions and a comparison of the adjusted coefficient of determination $\left(r^{2}\right)$ (Kvalseth 1985) were both used to decide on the best developmental model for each life-stage. Individual variation among mountain pine beetles was incorporated using a distribution model based on the "same shape" approach of Sharpe et al. (1977). The distributions of developmental times at each temperature were normalized by dividing each observation by the median developmental time at that temperature, producing one curve representative of all temperatures. These data were then fitted to one of three distribution models (Table 1).

A cohort is defined as the individuals in a particular life-stage that are approximately the same chronological age, or, in the model, the individuals that enter a particular lifestage during the same simulation time step (Logan et al. 1979). Transfer of individuals from one life-stage to the next is based on advancement of physiological age, which is defined as the summation of physiological time since the cohort was initiated. Physiological time, which is a combination of calendar time and temperature, is defined as:

$$
P\left(t_{1}\right)={ }_{t_{0}} \int^{t_{1}} R[T(t)] \mathrm{d} t
$$

where $P\left(t_{1}\right)$ is the physiological time at calendar time $t_{1}$, and $R$ is the development rate, which is a function of temperature $(T)$, which in turn is a function of time $(t)$. An algorithm based on this cohort concept and described by Logan (1988) was used to update and keep track of the population age structure in the model. 
Functional forms of the developmental rate and distribution models used for describing mountain pine beetle phenology

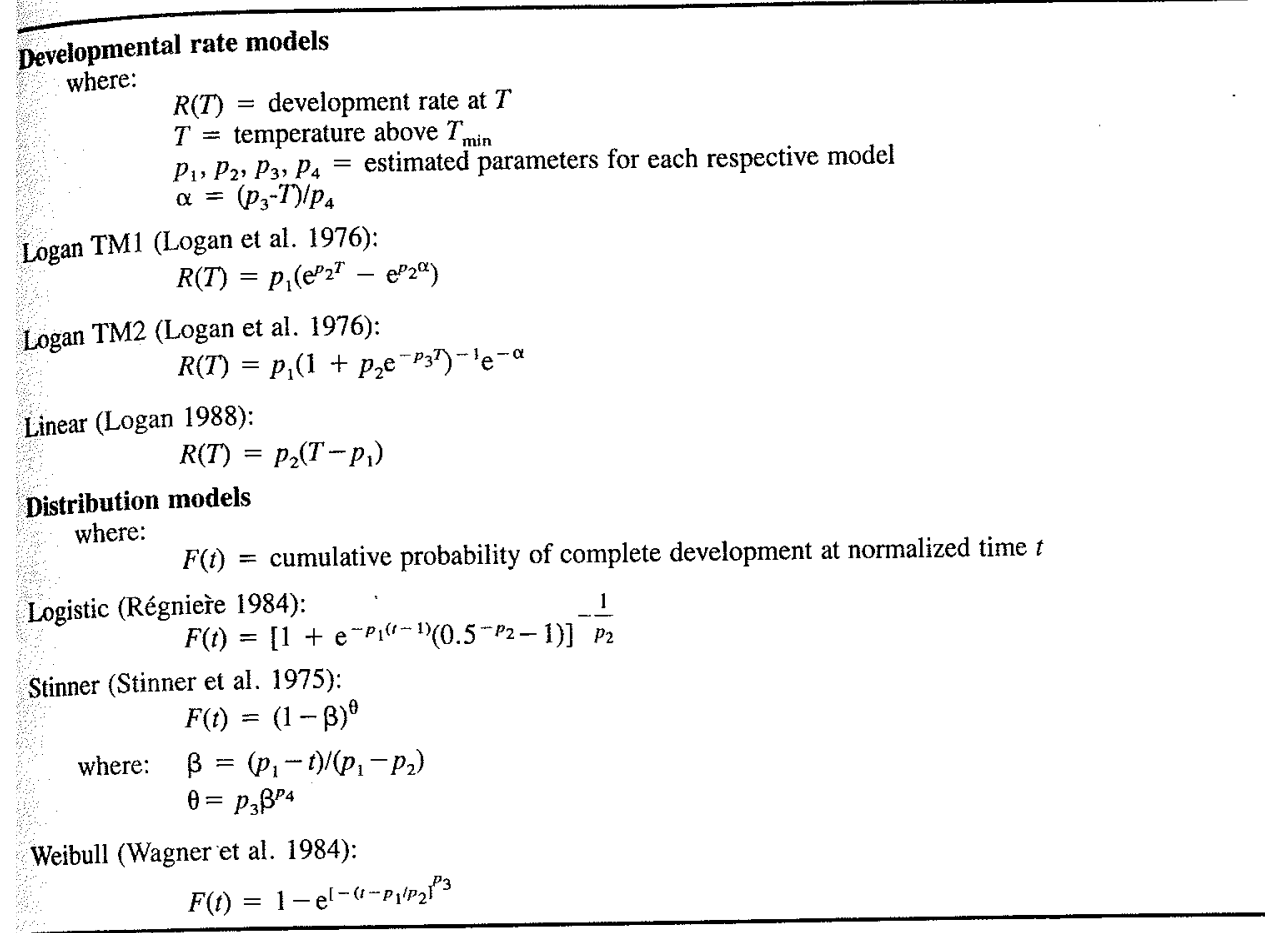

\section{Results and Discussion}

The controlled constant-temperature rearing experiments provided knowledge of the temperature thresholds and developmental time for the egg, larval, and pupal life-stages. Using this information, we were able to develop a temperature-dependent phenology model that simulates mountain pine beetle development. The selected developmental and distribution models, and estimated parameter values for each life-stage, are listed in Tables 1 and 2. The associated fits of the functional forms to observed data are in Figures 2 and 3.

Optimum temperatures for development in all life-stages were between 23 and $25^{\circ} \mathrm{C}$ (Fig. 2), which agrees with findings of Reid and Gates (1970) and Safranyik and Whitney (1985). In laboratory experiments, Safranyik and Whitney (1985) observed that 30.2 days were required for development from egg to adult at a constant $24^{\circ} \mathrm{C}$; Whitney and Spanier (1982) reported 31 days. Initiating the phenology model with 100 eggs and simulating development at a constant $24^{\circ} \mathrm{C}$ produced similar results. Fifty percent of the individuals reached the teneral adult stage after 28 days.

Phloem temperature measurements in an infested lodgepole pine provided knowledge of the environmental conditions experienced by developing mountain pine beetles (Fig. 4). Results from model simulation using these hourly phloem temperatures are depicted in Figure 5. The model was initiated with 100 eggs on Julian day 222, which was during the time when beetles were dispersing to new hosts in the stand. The duration in each lifestage is governed by the phloem temperatures occurring during that time period. The timing of molting for each larval instar and for pupal eclosion to teneral adults, and the life-stage depicted as overwintering (fourth-instar larvae), agree with the knowledge of mountain pine beetle biology and field observations made by the authors. 
Table 2. Estimated parameter values, adjusted $r^{2}$, and sample sizes $(N)$ for developmental and distribution models

\begin{tabular}{|c|c|c|}
\hline Life-stage & Developmental rate model & Distribution model \\
\hline Egg & $\begin{array}{l}\text { Logan TM1 } \\
p_{1}=0.029763 \\
p_{2}=0.141571 \\
p_{3}=22.51464 \\
p_{4}=3.164244 \\
N=156 \\
r^{2}=0.979\end{array}$ & $\begin{array}{l}\text { Weibull } \\
p_{1}=0.4933408 \\
p_{2}=6.9159520 \\
p_{3}=0.5411934\end{array}$ \\
\hline Instar I & $\begin{array}{l}\text { Logan TM2 } \\
p_{1}=1.018901 \\
p_{2}=72.24579 \\
p_{3}=0.339336 \\
p_{4}=24.22940 \\
p_{5}=4.307345 \\
N=83 \\
r^{2}=0.984\end{array}$ & $\begin{array}{l}\text { Weibull } \\
p_{1}=0.2071156 \\
p_{2}=4.7405750 \\
p_{3}=0.8722730\end{array}$ \\
\hline Instar II & $\begin{array}{l}\text { Logan TM2 } \\
p_{1}=1.001610 \\
p_{2}=36.70492 \\
p_{3}=0.377676 \\
p_{4}=18.33516 \\
p_{S}=3.905421 \\
N=49 \\
r^{2}=\text { na* }^{*}\end{array}$ & $\begin{array}{l}\text { Weibull } \\
p_{1}=0.0034052 \\
p_{2}=2.2482860 \\
p_{3}=1.2160780\end{array}$ \\
\hline Instar III & $\begin{array}{l}\text { Logan TM1 } \\
p_{1}=0.078989 \\
p_{2}=0.085548 \\
p_{3}=13.04908 \\
p_{4}=1.509073 \\
N=24 \\
r^{2}=\text { na* }^{*}\end{array}$ & $\begin{array}{l}\text { Logistic } \\
p_{1}=8.138001 \\
p_{2}=1.941817\end{array}$ \\
\hline Instar IV & $\begin{array}{l}\text { Linear } \\
p_{1}=10.93365 \\
p_{2}=0.010013 \\
N=37 \\
r^{2}=0.951\end{array}$ & $\begin{array}{l}\text { Stinner } \\
p_{1}=0.388004 \\
p_{2}=24.88443 \\
p_{3}=0.562433 \\
p_{4}=46.50753 \\
r^{2}=0.743\end{array}$ \\
\hline Instar V & $\begin{array}{l}\text { Linear } \\
p_{1}=13.09982 \\
p_{2}=0.022251 \\
N=18 \\
r^{2}=0.9847\end{array}$ & $\begin{array}{l}\text { Logistic } \\
p_{1}=36.42710 \\
p_{2}=4.200781 \\
r^{2}=0.747\end{array}$ \\
\hline
\end{tabular}

*Insufficient degrees of freedom for computation of $r^{2}$.

Results from the constant-temperature experiment revealed that the advanced lifestages (larval instars III, IV, and pupae) required higher temperatures for development than did eggs, instar I, or instar II (Fig. 2). Additionally, eggs, and larval instars I and II were able to develop over a much wider temperature range. These results and previous observations indicate that each of the mountain pine beetle life-stages examined has a specific optimal temperature regime and threshold for development. We hypothesize that this interaction between temperature and development results in an inherent mechanism for synchronizing larval instar molts and adult emergence. The evolution of this life-history "strategy" has allowed the mountain pine beetle to maximize fitness in a constantly changing environment. Two particular advantages may result from these positive influences. 

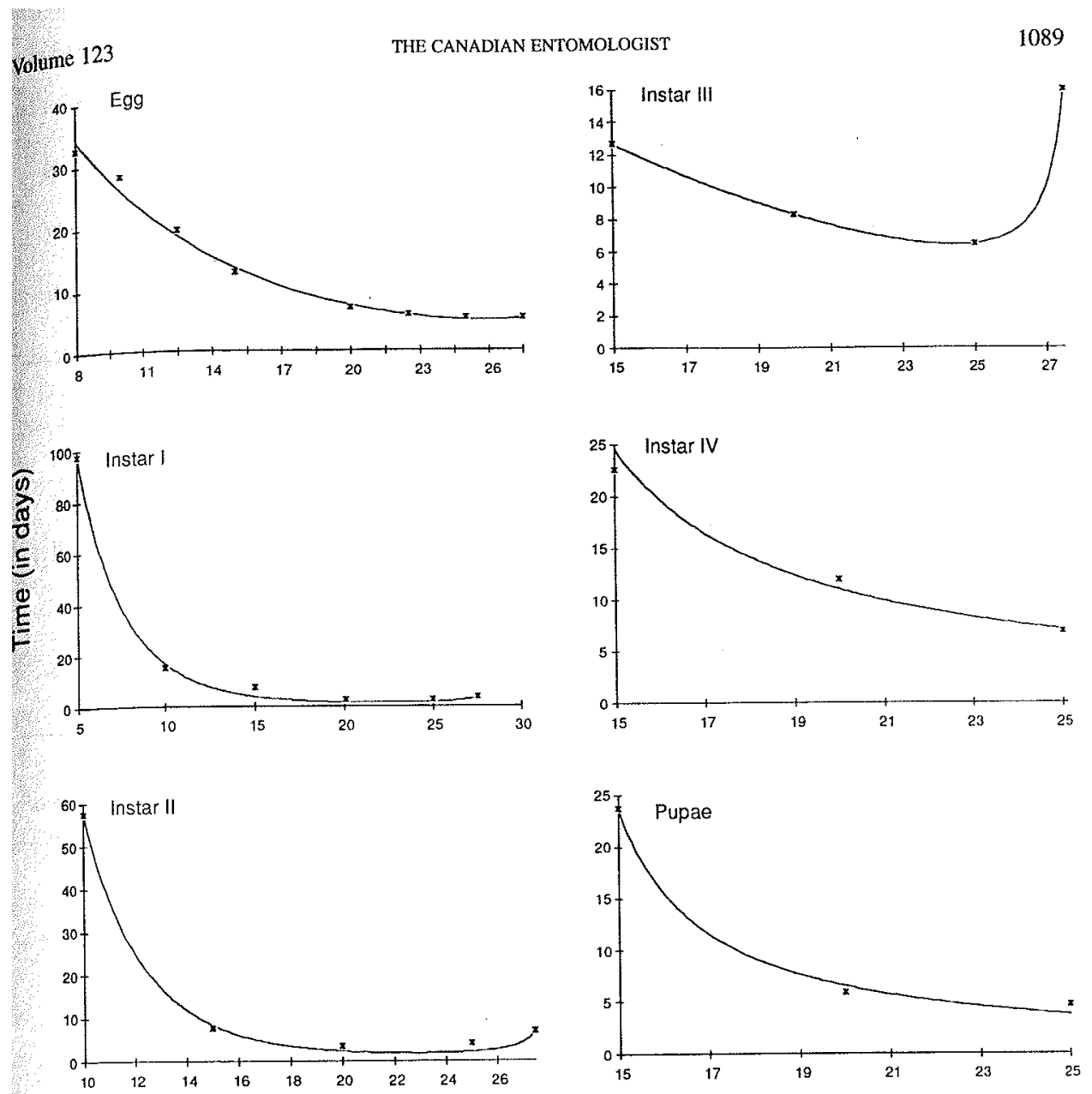

Temperature

Fig. 2. Developmental time functions for eggs, larval instars, and pupae fit to median times at constant temperatures. Equations and estimated parameters for developmental functions are in Tables 1 and 2. Curves represent the time (in days) to complete the life-stage at each constant temperature.

First, higher temperature thresholds of development in larval instars III and IV prevent progression to advanced life-stages (pupae, teneral adult, adult) which are highly susceptible to winter-kill (Reid 1962, 1963; Amman and Cole 1983). This delayed progression occurs when cooler temperatures in the fall slow development in the third- and fourthinstar larvae. Second, synchrony in development is accomplished when larvae from latehatching eggs are able to "catch up" in development after temperatures are too cool for the later instars to develop. Development in third-and fourth-instar larvae will halt in the cooler temperatures, but eggs and first- and second-instar larvae continue to develop at lower developmental thresholds. Eventually, this "catch up" allows for coincident adult emergence. Temporally synchronized eclosion encourages en masse attack, thus enabling beetles to overcome the defenses of larger diameter host trees. Because larger diameter trees provide more food (phloem) for the developing brood, coincident adult emergence eventually may lead to an epidemic population. 

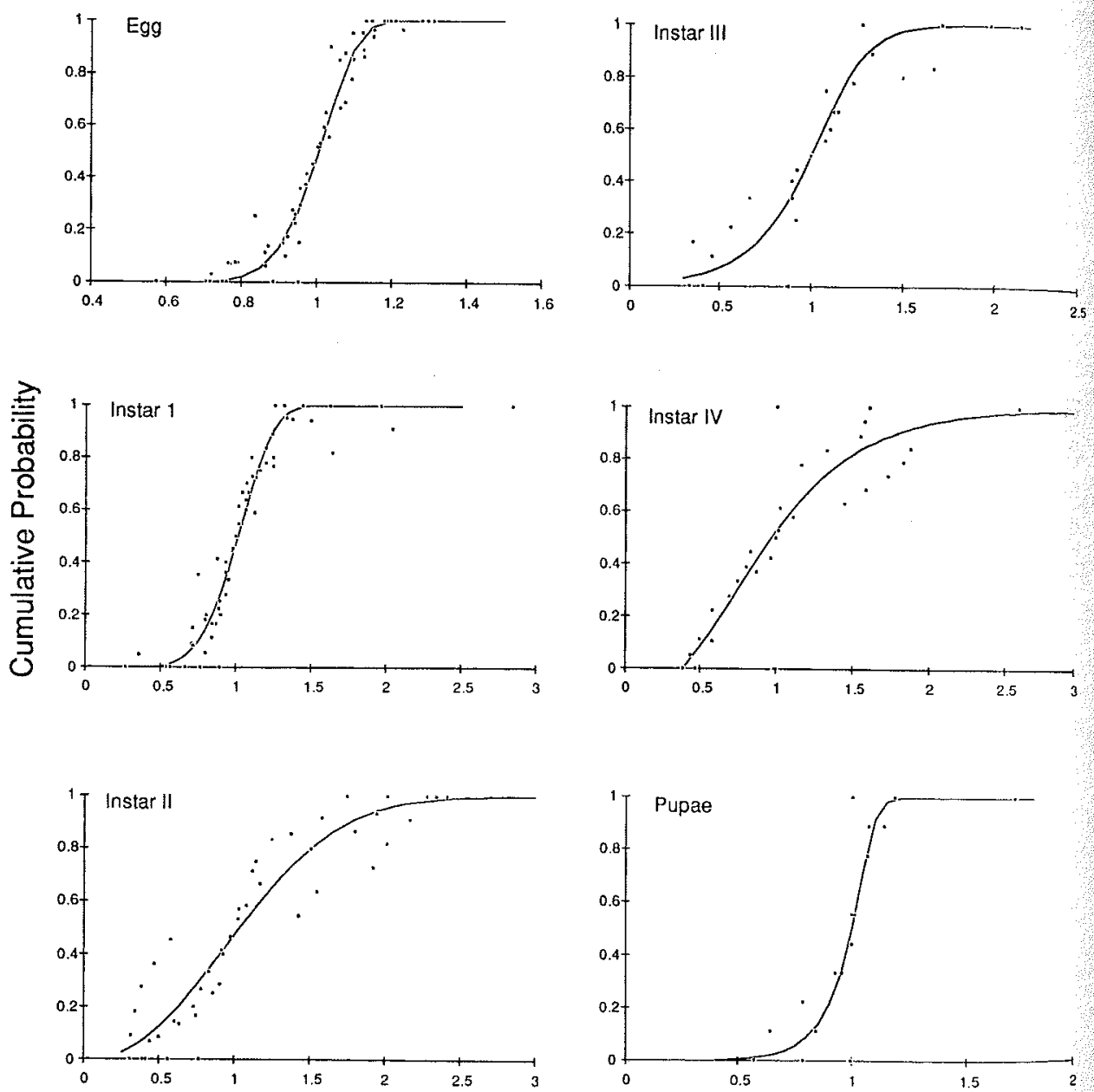

\section{Normalized Time}

FIG. 3. Predicted cumulative probability of emergence for eggs, larval instars, and pupae compared with observed normalized values. Equations, estimated parameters, and sample sizes for distribution functions are in Tables 1 and 2.

Using the developed phenology model and field-recorded phloem temperatures, we were able to test this hypothesis. The model was initiated with a range of egg cohorts dispersed over several days hypothetically representing a wide oviposition distribution. If our thermal threshold hypothesis is valid, inherent temperature thresholds and flexibility in development of each life-stage should allow for eventual synchrony and coincident adult emergence as individuals pass through the life cycle. Phloem temperatures from both the north and south side of the bole were used to drive the model.

The model was initiated with three different recruitment levels of egg cohorts: (1) 100 eggs laid during l day; (2) 100 eggs laid over 10 days; and (3) 100 eggs laid over 20 days. A comparison of model-predicted results using phloem temperatures from the north side of the bole is shown in Figure 6. In larval instar I, the timing of development and eclosion among the three recruitment levels was widely dispersed, but less so by the time individuals 


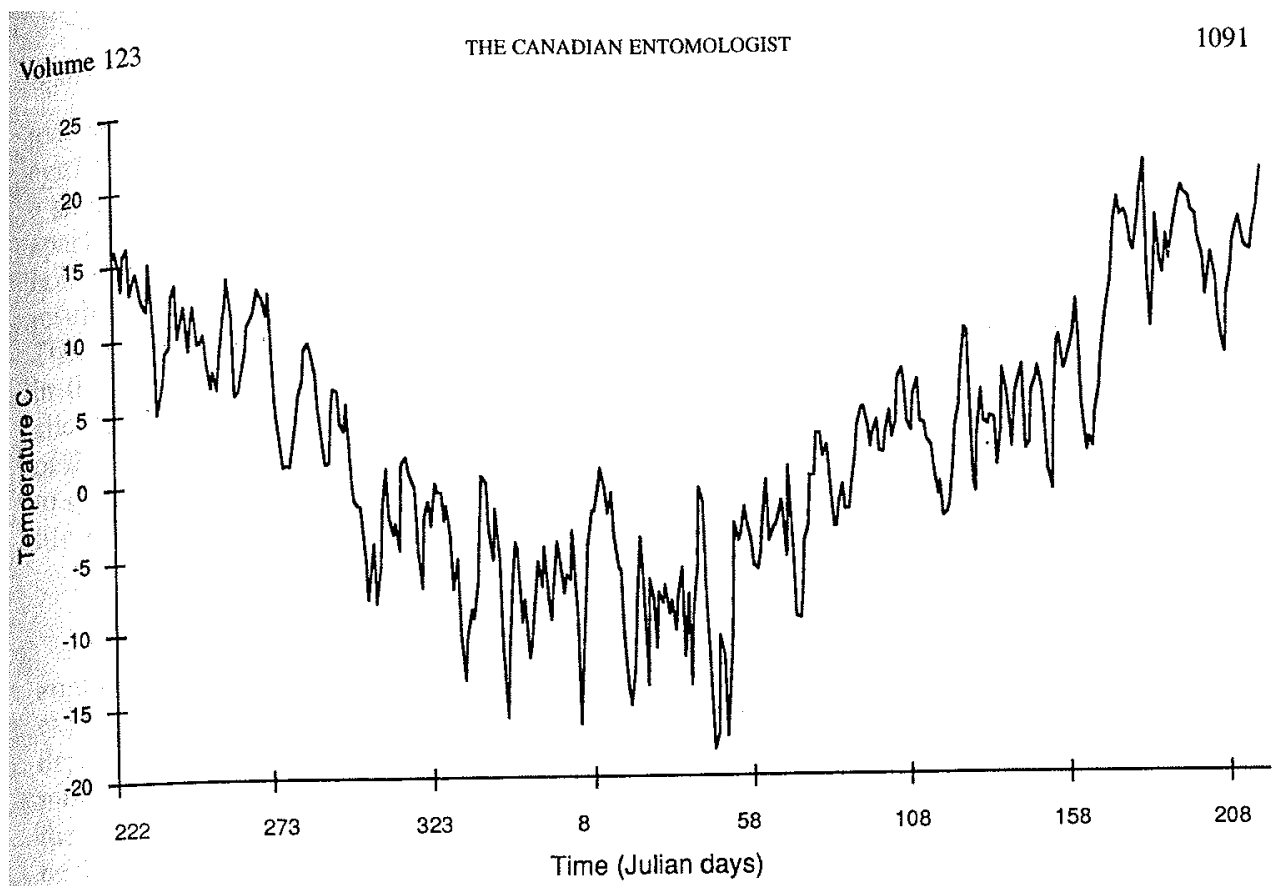

FrG 4. Average daily phloem temperatures $\left({ }^{\circ} \mathrm{C}\right.$ ) measured on the north side of a $25.1 \mathrm{~cm}$ dbh lodgepole pine in the Sawtooth National Recreation Area, ID, infested with mountain pine beetles.

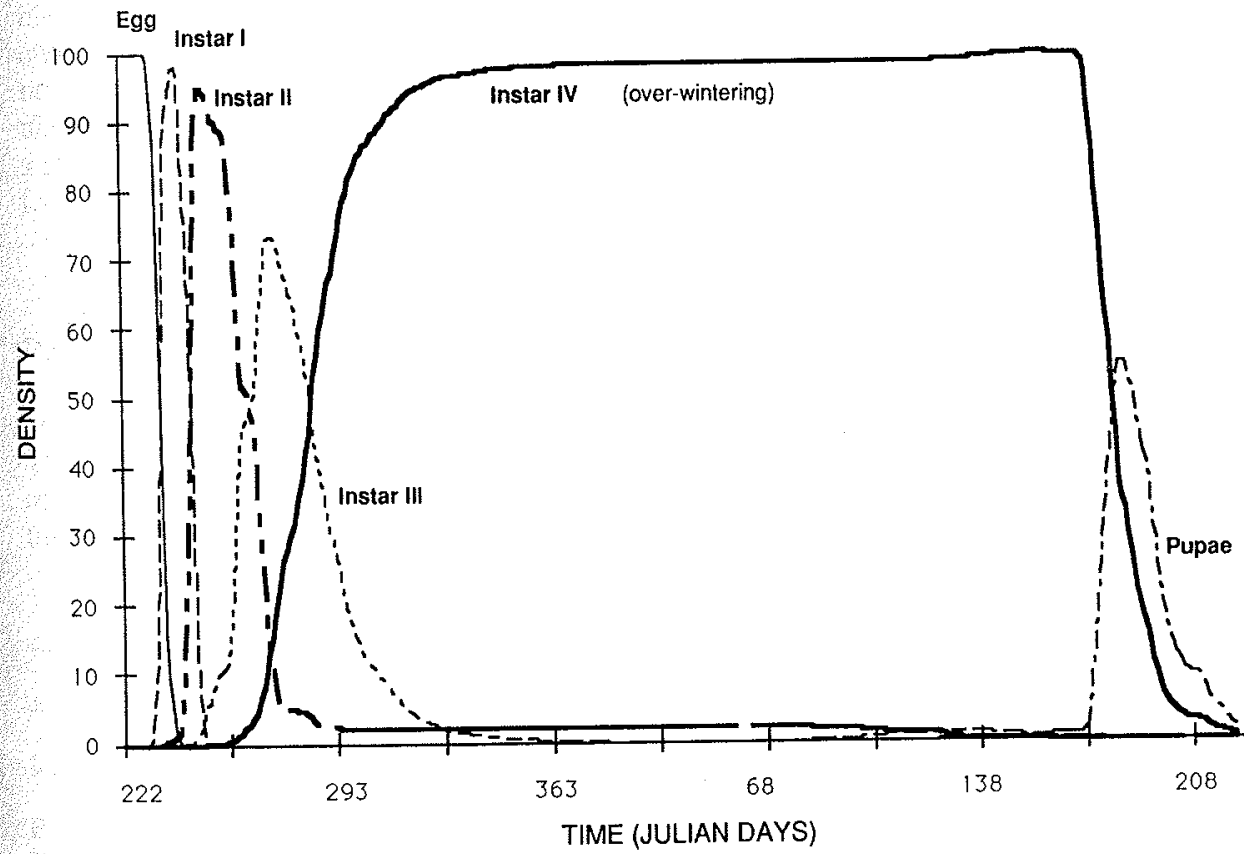

Fro. 5. Density in each life-stage predicted by the phenology model using phloem temperatures from an infested lodgepole pine in the Sawtooth National Recreation Area, ID. The model was initiated with 100 eggs on Julian day 222 . 


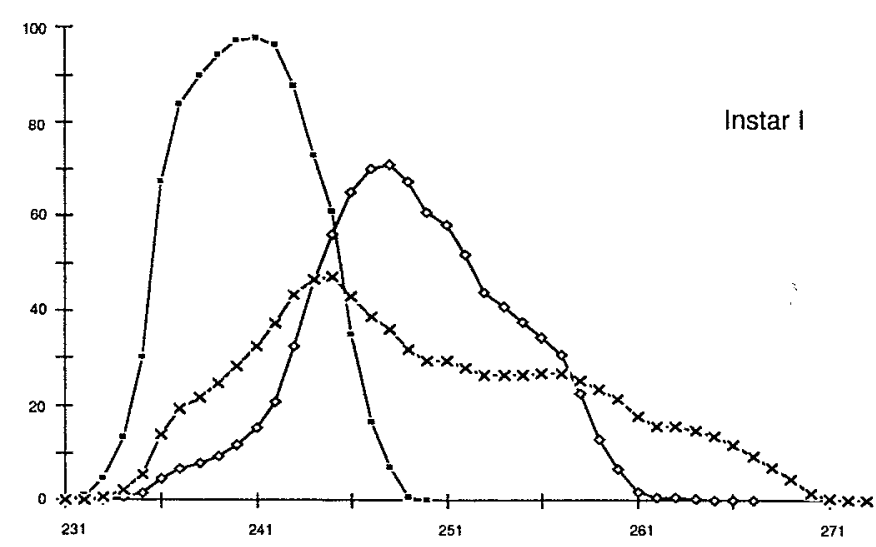

$$
\begin{aligned}
& \times 1 \text { Cohon } \\
& \times 10 \text { Cohorts } \\
& \times 20 \text { cohorts }
\end{aligned}
$$
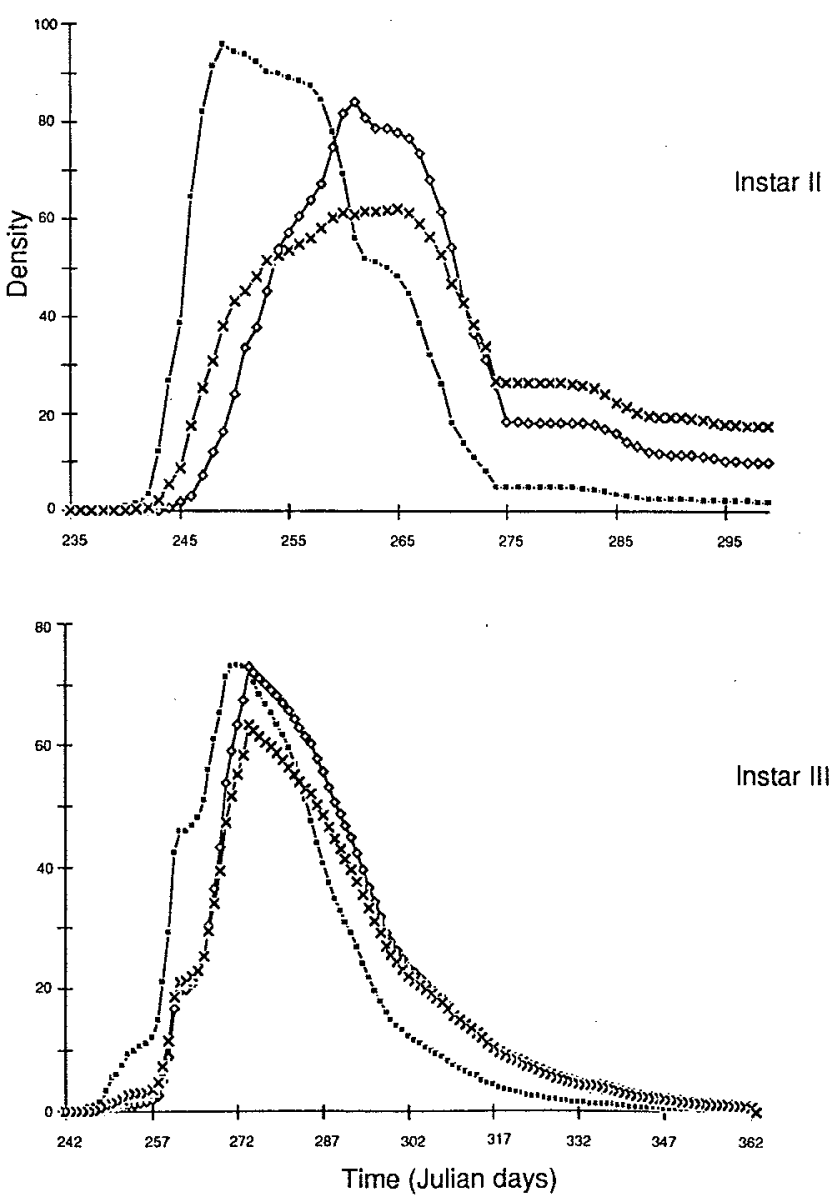

FIG. 6. Density of larvae in instar I, instar II, and instar III showing the temporal synchrony predicted by the simulation model. The phenology model was initiated on Julian day 222 with three recruitment levels of egg cohorts: 1 cohort (100 eggs laid on a single day), 10 cohorts (100 eggs laid over 10 days), and 20 cohorts (100 eggs laid over 20 days). Note the differences in time scale among instars. 
teached larval instar II. After molting to larval instar III, the individuals developing from eggs laid over a 20 -day period were temporally synchronized with those developing from a single cohort (eggs laid on a single day), and entered the fourth instar only a few days apart. A similar outcome occurred when phloem temperatures from the south side of the bole were used to drive the model. Although the warmer, southern exposure temperatures resulted in faster development in all instars, molting to the fourth-instar was coincident. These results suggest that, in this temperature regime, the late-hatching eggs "catch up" in the third larval instar. Although the proportion of individuals in each life-stage was altered, the ultimate timing of eclosion to the teneral adult was coincident, independent of the initial recruitment distribution. These observations imply that seasonality can serve to synchronize phenology, and that inherent thermal thresholds may indeed be an important life-history strategy for the mountain pine beetle.

\section{Summary}

Phloem temperature measurements of infested lodgepole pine trees revealed the large amount of daily fluctuations and extreme temperatures to which mountain pine beetles are exposed. Constant-temperature experiments provided a measure of the temperaturedependent development in the eggs, larval instars, and pupae. The developed phenology model uses both of these to simulate development of individual mountain pine beetles in the phloem of lodgepole pine trees. Results from this study indicate that mountain pine beetle life-stages have different thermal thresholds and developmental time functions that together tend to synchronize individuals of distinct cohorts for eventual coincident adult emergence. Because seasonal temperature cycles are universal, this life-history strategy may also be found in other insect species.

The ability to predict life-stage specific phenological development of mountain pine beetles in lodgepole pine has important applications for both management and research endeavors. This phenological model will help in our understanding of the interaction among beetle, stand, and at least one environmental factor, temperature, which influences population dynamics. As additional information of mortality and oviposition are included, and field measurements for validation are obtained, the utility of the model as a component for mountain pine beetle management and population research will be increased.

\section{Acknowledgments}

We acknowledge with thanks reviews of this manuscript by Thomas Payne, William Ravlin, and Nick Stone, Virginia Polytechnic Institute and State University, Blacksburg, VA. The use of trade or firm names in this paper is for reader information only and does not imply endorsement by the U.S. Department of Agriculture of any product or service. This publication was supported by a Cooperative Research Agreement between the Intermountain Forest and Range Experiment Station, USDA-FS, and Virginia Polytechnic Institute and State University.

\section{References}

Amman, G.D. 1973. Population changes of the mountain pine beetle in relation to elevation. Environ. Ent. 2(4): 541-547.

Amman, G.D., and W.E. Cole. 1983. Mountain pine beetle dynamics in lodgepole pine forests. Part II: Population dynamics. USDA For. Serv. Gen. Tech. Rep. INT-145.

Bartos, D.L., and G.D. Amman. 1989. Microclimate: An alternative to tree vigor as a basis for mountain pine beetle infestations. USDA For. Serv. Res. Pap. INT-400.

Beal, J.A. 1934. Relation of air and bark temperatures of infested ponderosae pines during subzero weather. J. econ. Ent. 27: 1132-1139.

Bedard, W.D. 1940. The relation of lipid and moisture content to cold-hardiness of mountain pine beetle larvae. Unpubl, Rep., USDA For. Serv.

Berryman, A.A. 1972. Resistance of conifers to invasion by bark beetle-fungus associations. Bioscience 22(10): 598-602. 
Cole, W.E. 1981. Some risks and causes of mortality in mountain pine beetle populations: A long-term analysis. Res. Popul. Ecol. 23(1): 116-144.

Kramer, D.A., R.E. Stinner, and F.P. Hain. 1991. Time versus rate in parameter estimation of nonlinear tem perature-dependent development models. Environ. Ent. 20: 484488.

Kvalseth, T.O. 1985. Cautionary note about $R^{2}$. Am. Statistician 39: 279-285.

Langor, D.W. 1989. Host effects on the phenology, development, and mortality of field populations of the mountain pine beetle. Can. Ent. 121: 149-157.

Logan, J.A. 1988. Toward an expert system for development of pest simulation models. Environ. Ent. 17(2): $359-376$.

Logan, J.A., and G.D. Amman. 1986. A distribution model for egg development in mountain pine beetle. Can. Ent. 118: 361-372.

Logan, J.A., R.E. Stinner, R.L. Rabb, and J.S. Bacheler. 1979. A descriptive model for predicting spring emergence of Heliothis zea populations in North Carolina. Environ. Ent. 8: 141-146.

Logan, J.A., D.J. Wolkind, S.C. Hoyt, and L.K. Tanigoshi. 1976. An analytical model for description of temperature dependent rate phenomenon in arthropods. Environ. Ent. 5: 1133-1140.

McCambridge, W.F. 1974. Influence of low temperatures on attack, oviposition, and larval development of mountain pine beetle Dendroctonus ponderosae (Coleoptera: Scolytidae). Can. Ent. 106: 979-984.

Powell, J.M. 1967. A study of habitat temperatures of the bark beetle Dendroctonus ponderosae in lodgepole pine. Agric. Meteor. 4: 189-201.

Régniere, J. 1984. A method of describing and using the variability in development rates for the simulation of insect phenology. Can. Ent. 116: 1367-1376.

Reid, R.W. 1962. Biology of the mountain pine beetle, Dendroctonus monticolae, in the east Kootenay region of British Columbia. I. Life cycle, brood development, and flight periods. Can. Ent. 94: 531-538. 1963. Biology of the mountain pine beetle, Dendroctonus monticolae, in the east Kootenay region of British Columbia. III. Interactions between the beetle and its host, with emphasis on brood mortality and survival. Can. Ent. 95: 225-238.

Reid, R.W., and H. Gates. 1970. Effect of temperature and resin on hatch of eggs of the mountain pine beetle (Dendroctonus ponderosae). Can. Ent. 102: 617-622.

Safranyik, L., and H.S. Whitney. 1985. Development and survival of axenically reared mountain pine beetles, Dendroctonus ponderosae (Coleoptera: Scolytidae), at constant temperatures. Can. Ent. 117: 185-192.

Sharpe, P.J.H., G.L. Curry, D.W. DeMichele, and C.L. Cole. 1977. Distribution model of organisms development times. J. Theor. Biol. 66: 21-28.

Stinner, R.E., G.D. Butler, J.S. Bacheler, and C. Tuttle. 1975. Simulation of temperature dependent development in population dynamic models. Can. Ent. 107: 1167-1174.

Wagner, T.L., H. Wu, P.J.H. Sharpe, and R.N. Coulson. 1984. Modeling distributions of insect development time: A literature review and application of the Weibull Function. Ann. ent. Soc. Am. 77: 475-483.

Whitney, H.S., and O.J. Spanier. 1982. An improved method for rearing axenic mountain pine beetles. Can Ent. 114: 1095-1100.

Wygant, N.D. 1942. Effects of low temperatures on the Black Hills beetle (Dendroctonus ponderosae). Unpubl. Rep., USDA For. Serv. Rocky Mountain Forest and Range Exp. Sta. 65 pp.

Yuill, J.S. 1941. Cold hardiness of two species of bark beetle in California forests. J. econ. Ent. 34: 702-709. (Date received: 14 May 1990; date accepted: 2 I March 1991) 